spur to COMSAT's progress. But it would be interesting to know whether national carriers outside the United States, usually national post offices, have studied all the implications of this military traffic in a satellite system which, as the United States Congress declared in 1962, is to "contribute to world peace and understanding".

\section{Rumour made Respectable}

The United States Air Force has at last conceded that the rumours of Unidentified Flying Objects do exist, though it has not yet gone so far as to endow the objects themselves with the reputation of reality. The Air Force has appointed a committee under Professor Edward Condon of the University of Colorado at Boulder, and has endowed a programme of work intended to occupy the next fifteen months with a grant of $\$ 313,000$. Evidently it is hoped that Professor Condon's reputation as a man who cannot be told what to do or think will give the conclusions of the study - whatever they may be - a readily demonstrable core of dependence. The other members of the enquiry include Dr. F. E. Roach, an astrophysicist, and Dr. S. W. Cook, a psychologist. The Air Force has promised access to all information. Eventually the National Academy of Sciences will review the report. Thus, in as little as two years, the world may know the truth about flying saucers.

\section{The Long View}

THE view that university development programmes can and should be planned thirty-five years ahead brought an audible gasp from some of the audience at the Royal Society Nuffield Lecture on October 25. Its advocate was Dr. C. J. Hitch, Assistant Secretary of Defense (Comptroller) in the United States since 1961 and previously head of the Economics Division at the Rand Corporation. His qualification to speak on the long-term planning of education is not entirely theoretical, for he is also the Vice-President responsible for Business and Finance at the University of California.

Dr. Hitch's concern is to apply the techniques of programme budgeting and systems analysis, or of operational research, to a host of problems in management. He claimed last week that the work so far carried out at the Department of Defense has been so successful that President Johnson has now decreed that other agencies of the United States Administration should follow suit. The United States Bureau of the Budget has been using these techniques to supplement its annual budgets with more distant forecasts. In education, Dr. Hitch held that it is necessary to look a generation ahead because it may often take that long for the educational system to respond to a major change in the external demands made on it. It remains to be seen whether there is an educational system in which the long-term objectives are not hopelessly obscured by the vicarious ups and downs of real government.

\section{Scottish Marine Research}

THE Scottish Marine Biological Association with laboratories in Millport and Edinburgh is about to build a new mainland laboratory near Oban, Argyll, as the first step in its plan for expanding research on the west coast of Scotland and the adjacent continental shelf. The Natural Environment Research Council, which became responsible for the Association in June, has approved the first instalment of the capital sum required for the new laboratory.

The work of the laboratory is oriented towards practical problems. Two workers at the marine station, Millport, have been investigating the effects on benthic macrofauna, notably molluscs, near the outfall of the Hunterston Nuclear Generating Station. They have been surprised to find that broods have begun to settle since the station began operating in August 1964; as yet the station has had no apparent effect on the molluscan fauna. Another study is concerned with the effects of effluents discharged into Loch Eil and Loch Linnhe by a pulp mill at Corpach. The oceanographic laboratory at Edinburgh has continued its plankton survey of the North Atlantic and North Sca, and has done its bit for foreign exchange by sclling a number of plankton recorders to universities overseas.

\section{U.K. Strontium-90}

AN analysis of strontium-90 in human bone samples in Britain, mostly from subjects who died between July and December 1965, has shown that the contamination has decreased significantly from the 1964 maximum for newborn and stillborn infants, according to the most recent report on the subject by the Medical Research Council (Assay of Strontium-90 in Human Bone in the United Kingdom, MRC Monitoring Report No. 13, H.M.S.O., $2 s .3 d$.). Because bone is replaced slightly more slowly in older children, similar results are expected for children under five in the next set of results covering the first half of 1966 . The adult level, while much lower than for children, still shows some increase, the result of the delayed effects of the nuclear weapon tests of 1961 and 1962. Analyses carried out by the U.K. Atomic Energy Authority are as follows, with the numbers indicating relative strontium-90 concentrations in bone (pc./g calcium):

$\begin{array}{lrr} & 1964 & 1965 \\ \text { Newborn and stillborn } & 3 \cdot() & 2 \cdot 5 \\ \text { Under 5 years (excluding newborn) } & 7 \cdot 1 & 6 \cdot 6 \\ \text { 6-23 months } & 8 \cdot 6 & 9 \cdot 0\end{array}$

Independent analyses carried out in Glasgow are slightly higher, probably because rainfall is greater in Scotland than in England. The Medical Research Council stresses that the potential risks attributable to the strontium-90 levels in these series are extremely small.

\section{Colloids at Bristol}

IN an attempt to teach surface chemistry and colloids at a fundamental level and thus to train people for work in these areas, the School of Chemistry of the University of Bristol started three years ago a postgraduate course in surface chemistry and colloids, leading to the degree of M.Sc. This year nine people are enrolled for the course compared with fourtcen last year and six in the first year. The students enrolled have come from many different universities and some have come from colleges of technology with the qualification of graduate of the Royal Institute of Chemistry. Of the students completing the course so far, about 50 per cent have carried on to study for the 